\title{
Profile characteristics of migrants, especially occupation and HIV status, accessing targeted interventions in Mumbai and Thane in India
}

\author{
${ }^{1}$ Public Health Foundation of India, India \\ ${ }^{2}$ Health Vision and Research, India \\ ${ }^{3}$ Tata Institute of Social Science, India \\ ${ }^{4}$ National Migration Unit (NMU), National AIDS Control Organisation, India
}

Debasish Chowdhury ${ }^{1}$, Saravanamurthy PS ${ }^{1}$, Arupkumar Chakrabartty ${ }^{2}$, Unnati Machhar ${ }^{1}$, Shantanu Purohit ${ }^{1}$, Sandhya Iyer ${ }^{3}$, Ashok Agarwal ${ }^{1}$, K.M. Gopal ${ }^{4}$, Pradeep Mishra ${ }^{1}$

\begin{abstract}
Introduction: Under National AIDS Control Program IV (NACP IV) during 2012-2017 in India, human immunodeficiency virus (HIV) prevention strategies under targeted intervention (TI) programs for migrants of different profiles were uniform. Role of the profile of migrants, especially their occupation, in the spread of HIV epidemic was not well-explored. The present study investigated the linkages between profile characteristics and occupations with HIV infection status of the migrants in Mumbai and Thane in Maharashtra, India.

Material and methods: This was a cross-sectional epidemiological study conducted among 24,864 migrants (males 23,908, 96.1\%, and females 956, 3.9\%) covered under the TI programs implemented in Mumbai and Thane districts of Maharashtra, India from April to December 2016. SPSS 20.0 version was used for analysis. At $95 \%$ confidence interval, $\chi^{2}$ test, Fishers exact test, and multiple logistic regression model were used for finding out factors associated with HIV infection status.

Results: Among the females, HIV infection rates were $4.4 \%$ and $1.3 \%$ in Mumbai and Thane, respectively, whereas for males, it was $0.3 \%$ in both the places. Predictors of HIV infection status in Mumbai were gender and type of persons staying with the migrant at the residence. For Thane, apart from these two, accompanying person during mobility played a certain role. In Thane, occupation in small to medium scale industry was the predictor of HIV infection but not in Mumbai.

Conclusions: Additional strategies for migrant intervention program had been left out in opportunities for NACP in India. We recommend that special strategies need to be developed in NACP to address these predictors of HIV infection.
\end{abstract}

HIV AIDS Rev 2018; 17, 3: 189-196 DOI: https://doi.org/10.5114/hivar.2018.78491

Key words: migrant, HIV, occupation, predictor.

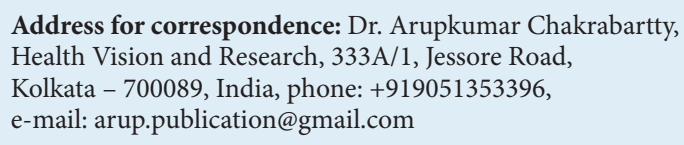

Article history:

Received: 14.12.2017

Received in revised form: 16.02.2018

Accepted: 22.02.2018

Available online: 15.08.2018
International Journal of HIV-Related Problems

HIV \& AIDS

R e v i e w 


\section{Introduction}

The National AIDS Control Program (NACP) in India has defined migrants as the people who move from their place of origin (primarily rural) to a town or city (destination) for the purposes of work, and they return to their place of origin periodically [1]. As per Census of India, migrants move from one political area to another [2]. In India, human immunodeficiency virus (HIV) prevalence among male migrants was estimated to be $0.99 \%$ in $2014-2015$, which was three times higher than the general population [3]. According to the estimates of Indian Council of Medical Research (ICMR) in 2009, HIV prevalence in India was $0.37 \%$ for males compared with $0.24 \%$ for females, that became $0.30 \%$ and $0.20 \%$, respectively for males and females in 2015. Estimated number of male people living with HIV (PLHIV) in 2009 was 1,342,940, and female PLHIV was 831,654 (male : female ratio $=1.61: 1$ ), which become 1,260,094 for males and 856,487 for females (male : female ratio $=1.47: 1$ ) in 2015 [4]. The overall velocity of HIV epidemic appeared to have been stabilized both globally and in India, but the numbers of new infections among migrants were still higher than expected [5]. People migrate either due to distress or for better livelihood opportunities from their place of home to other places $[1,6]$. Migrants bear a heightened risk of HIV infection, which results from the condition and structure where migration takes place. Occupation is one of parameters of these conditions and structures where HIV risks are prevailing [7, 8]. Female garment factory workers in Cambodia were more exposed to HIV/ AIDS than previously thought. This means that a certain occupation had positive linkage with HIV epidemic, especially for this occupation group [9]. There is limited information available on different types of their occupation and how these varieties of occupation influence their mobility, duration of stay at destination, number of visits to homes, and also access to HIV services and ultimately the spread of the HIV epidemic. Occupation is the driving force behind migration and it shapes their lifestyles. There is a need for further research to put more insight into their occupation and its linkages with sexual behavior and HIV epidemic among the migrants $[9,10]$.

Public Health Foundation of India (PHFI) during NACP IV 2012-17, implemented a project called impact through prevention, private sector and evidence-based programming (PIPPSE)' in six states of India, out of which Mumbai district in Maharashtra was an example. This is a preferred place of destination for migrants from all over India. Mumbai as a host site, offers wide ranges of occupational choices to the migrants. In the late nineties, the migrants from Uttar Pradesh and Bihar continue to be in larger proportion in Mumbai than the non-migrants, and also migrants from within the state [11].

From the experiences of Mumbai and Thane of Maharashtra through the project during 2012-17, PIPPSE, PHFI generated a large primary data set on the migrants. This dataset was analyzed to investigate different occupations of the migrants and its linkages with sexual behaviors and HIV infection status. In this study, we explored linkages be- tween occupational varieties with sexual behaviors of the migrants and HIV infection status among the migrants.

\section{Material and methods}

\section{Type of the study and the area}

This was a cross-sectional epidemiological study conducted among the migrants covered under the targeted intervention (TI) programs implemented in Mumbai and Thane district of Maharashtra, India under the National AIDS Control Program IV (NACP IV) during 2012-2017, implemented by National AIDS Control Organization, Government of India.

\section{Data source}

The migrants, registered by the targeted intervention (TI) program for HIV prevention in Mumbai and Thane, were respondents of this analysis. Information on the socio-demographic profile, occupation, HIV-associated risk behavior, family details, and other related information of 52 indicators from the migrants were collected by outreach workers or counsellors of the TIs' using the 'registration form' prescribed by the national HIV program. Data collected during April to December 2016 were entered in the online web-based tool called 'migrant service delivery system (MSDS)' on weekly basis by a monitoring and evaluation officer to ensure tracking of services for migrants at the destination. Finally, at the end of 2016, the information entered in MSDS was downloaded for analysis. After editing the whole data set, information collected for 24,864 migrants were analyzed.

\section{Migrant service delivery system}

The migrant service delivery system (MSDS) was a tool to facilitate effective utilization of data from different sources (program outreach and services) at the source and destination level, and linking of data across destination and source programs for robust planning, implementation, and monitoring. Due to linked data, it helped to provide inputs to implementing and management team to enhance service availability by managing individuals or groups in the migrant continuum. Basically, it was able to provide information to improve access to services for migrants and their spouses based on analysis of the movement of individuals or groups, on their risk profile, and on healthcare seeking behavior over a period of time. MSDS was a web-enabled tool, which could work both online and offline, and was compatible with strategic information management system (SIMS) of NACO and upgradable for additional features.

\section{Indicators for the analysis}

The analysis was competed for the migrants broadly on three areas: profile of the respondents, their occupation, and HIV infection status. 
As per the NACO guidelines, occupation was classified in four broad categories - laborers (construction worker, daily wager, daily laborer, hawker, hotel worker, motor mechanic, skilled worker, carpenter, driver, plumber, wall painting, security guard), small and medium enterprises (diamond worker, dairy worker, quarry worker, moti worker), large industry/ancillary unit (industrial worker and loom worker), and home-makers.

\section{Data analysis}

Information collected on 24,864 migrants (males 23,908, $96.1 \%$, and females $956,3.9 \%$ ) were analyzed. Even though the proportion of female migrants was much lower than the males, this difference did not affect our analysis because of the very large sample size. We used SPSS 23.0 version for the analysis. We used $\chi^{2}$ test and Fishers exact test at the $95 \%$ confidence interval (CI) for finding the association between participant characteristics and HIV infection status. Using multiple logistic regression model at $95 \%$ confidence interval, we identified the predictors for HIV infection separately for Mumbai and Thane district.

\section{Limitations}

The study was conducted based on the information downloaded from MSDS and purely relied on the TIs' for its quality. Cross-validation of data between information from the MSDS and the records available in the TIs' were not made.

\section{Results}

\section{Participant characteristics}

The study was conducted among 24,864 migrants, out of which 23,908 (96.1\%) were males and 956 (3.9\%) were females. The major age groups, from 19-24 years included 8,113 persons $(32.6 \%)$, and from $25-35$ years counted 10,035 (40.3\%). Among respondents, 3,331 (13.4\%) were illiterate. Among different occupations, there were 15,208 (61.2\%) laborers, small and medium enterprise counted 337 (1.4\%), large industry or ancillary counted 9,181 (36.9\%), and home-makers counted 138 (0.6\%). Further details of the participant characteristics, separately for Mumbai and Thane are provided in Table 1.

\section{Epidemiology of HIV infection: participant characteristics and their occupation}

The overall HIV infection rate among migrants in Mumbai was $0.34 \%$, and in Thane it was $0.39 \%$. Among the female migrants, HIV infection rate was $4.4 \%$ in Mumbai, compared with $1.3 \%$ in Thane. Among the males, the infection rate was $0.3 \%$ in both the places. HIV infection rate in Mumbai was $1.0 \%$ among persons of age up to 18 years (highest in youngest age group), compared to $3.6 \%$ among persons age more than 49 years in Thane (highest in this age group). Literacy did not much differ in the infection rate. Among the married and unmarried groups, the infection rate was the same $(0.5 \%$ both for males and females in Mumbai and Thane). For migrants moving not in groups, the infection rate was higher $(0.7 \%$ in Mumbai and as $8.0 \%$ in Thane). According to NACO categorization, the type 'other' was not well defined. The infection rate was $1.9 \%$ in Mumbai among migrants staying with their family, which was $1.5 \%$ in Thane. There was not much difference. Migrants working in small or medium industries had $0.8 \%$ infection rate in Mumbai, compared with 3.3\% in Thane. Table 1 presents further details of the epidemiology of HIV infection.

\section{Association between participant characteristics and HIV infection}

\section{In Mumbai}

We looked at the distribution of HIV infection status separately for two districts, Mumbai and Thane, based on the characteristics of the migrants, especially on different types of occupations. In Mumbai, HIV infection status was found significantly associated with gender $(p=0.001)$, marital status $(p=0.001)$, and staying with family members or not $(p=0.001)$ (Table 1$)$. Doing multiple logistic regression, we could see that in Mumbai, among different characteristics of the migrants, gender $(p=0.001$, OR: 8.652 ; 95\% CI: 3.217-23.268) and their accompanying person at residence in destination (either staying with the family or not) ( $p=0.001$; OR: 4.94; 95\% CI: 2.14-11.43) were important predictors of HIV infection status. In Mumbai, none of the aspects were a predictor factor for HIV infection (Table 2).

\section{In Thane}

HIV infection status was significantly associated with gender $(p=0.001)$, age group $(p=0.001)$, marital status $(p=0.001)$, mobility with accompanying persons $(p=0.011)$, duration of stay at destination $(p=0.005)$, staying with family members or not $(p=0.001)$, and occupation $(p=0.001)$ (Table 1$)$. In Thane, among different characteristics of the migrants, younger age groups (19-24 years, 25-35 years, and 36-49 years) were less likely to be HIVinfected than the aged groups ( $>49$ years). Migrants who had moved alone or with broker or contractor were less likely to become HIV-infected than other variety. Migrants staying with family members were more likely to become HIVinfected than those who were staying with other than family members ( $p=0.000$; OR: 5.827: 95\% CI: 2.483-13.676).

Migrants from the occupation of small or medium enterprises (diamond worker, dairy worker, moti worker, and quarry worker) were more likely to get HIV-infected than homemaker groups ( $p=0.001$; OR: 7.971, 95\% CI: 2.99921.189) (Table 2). 
Table 1. Characteristics and HIV infection status of the migrants in Mumbai and Thane, India

\begin{tabular}{|c|c|c|c|c|c|c|c|}
\hline \multirow{2}{*}{ Factor } & \multirow{2}{*}{$n(\%)$} & \multicolumn{3}{|c|}{ Mumbai } & \multicolumn{3}{|c|}{ Thane } \\
\hline & & HIV+, $n(\%)$ & HIV-, $n(\%)$ & $p$ value & HIV+, $n$ (\%) & HIV-, $n$ (\%) & $p$ value \\
\hline \multicolumn{8}{|l|}{ Gender } \\
\hline Male & $23,908(96.2)$ & $42(0.3)$ & $13,623(99.7)$ & \multirow[t]{2}{*}{0.001} & $33(0.3)$ & $10,210(99.7)$ & \multirow[t]{2}{*}{0.001} \\
\hline Female & $956(3.8)$ & $6(4.4)$ & $131(95.6)$ & & $11(1.3)$ & $808(98.7)$ & \\
\hline \multicolumn{8}{|l|}{ Age group } \\
\hline Up to 18 years & $1,110(4.5)$ & $1(1.0)$ & $1,030(99.9)$ & \multirow[t]{5}{*}{0.173} & $0(0.0)$ & 79 (100.0) & \multirow[t]{5}{*}{0.001} \\
\hline $19-24$ years & $8,113(32.6)$ & $8(0.2)$ & 4,759 (99.8) & & $5(0.1)$ & 3341 (99.9) & \\
\hline $25-35$ years & $10,035(40.4)$ & $17(0.3)$ & $5,454(99.7)$ & & $20(0.4)$ & 4,544 (99.6) & \\
\hline $36-49$ years & $5,406(21.7)$ & $21(0.9)$ & 2,395 (99.1) & & $16(0.5)$ & 2,974 (999.5) & \\
\hline$>49$ years & $200(0.8)$ & $1(0.9)$ & $116(99.1)$ & & $3(3.6)$ & $80(96.4)$ & \\
\hline \multicolumn{8}{|l|}{ Education } \\
\hline Illiterate & $3,331(13.4)$ & $4(0.3)$ & $1,209(99.7)$ & \multirow[t]{5}{*}{0.198} & $6(0.3)$ & $2,112(99.7)$ & \multirow[t]{5}{*}{0.173} \\
\hline Just literate & $3,637(14.6)$ & $3(0.3)$ & $1,056(99.7)$ & & $15(0.6)$ & $2,563(99.4)$ & \\
\hline Up to $5^{\text {th }}$ class & $6,902(27.8)$ & $20(0.5)$ & $4,284(99.5)$ & & $14(0.5)$ & $2,584(99.5)$ & \\
\hline Up to $9^{\text {th }}$ class & $6,369(25.6)$ & $13(0.3)$ & $4,342(99.7)$ & & $5(0.2)$ & 2,009 (99.8) & \\
\hline $10^{\text {th }}$ and above & 4,625 (18.6) & $8(0.3)$ & $2,863(99.7)$ & & $4(0.2)$ & $1,750(99.8)$ & \\
\hline \multicolumn{8}{|l|}{ Marital status } \\
\hline Married & $15,784(63.5)$ & $38(0.5)$ & $7,620(99.5)$ & \multirow[t]{2}{*}{0.001} & $42(0.5)$ & $8,084(99.5)$ & \multirow[t]{2}{*}{0.001} \\
\hline Never married & $9,080(36.5)$ & & & & & & \\
\hline \multicolumn{8}{|l|}{ Mobility with } \\
\hline Broker/contractor & $2,014(8.1)$ & $2(0.1)$ & $1,626(99.9)$ & \multirow[t]{4}{*}{0.041} & $1(0.3)$ & $395(99.7)$ & \multirow[t]{4}{*}{0.011} \\
\hline Groups & $15,047(60.5)$ & $19(0.3)$ & $6,823(99.7)$ & & $27(0.3)$ & $8,178(99.7)$ & \\
\hline Alone & $7,323(29.5)$ & $24(0.5)$ & $4,926(99.5)$ & & $9(0.4)$ & $2,364(99.6)$ & \\
\hline Other type & $512(2.1)$ & $3(0.7)$ & $421(99.3)$ & & $7(8.0)$ & $81(92.0)$ & \\
\hline \multicolumn{8}{|l|}{ Stay at destination } \\
\hline$\leq 1$ year & $6,440(25.9)$ & $10(0.3)$ & $2,877(99.7)$ & \multirow[t]{3}{*}{0.846} & $6(0.2)$ & $3,547(99.8)$ & \multirow[t]{3}{*}{0.005} \\
\hline$>1-5$ years & $15,085(60.7)$ & $32(0.3)$ & $9,450(99.7)$ & & $28(0.5)$ & $5,575(99.5)$ & \\
\hline$>5$ years & $3,339(13.4)$ & $6(0.4)$ & $1,427(99.6)$ & & $11(0.6)$ & $1,895(99.4)$ & \\
\hline \multicolumn{8}{|l|}{ Staying with } \\
\hline Family members & $1,723(6.9)$ & $9(1.9)$ & $460(98.1)$ & \multirow[t]{2}{*}{0.001} & $19(1.5)$ & $1,235(98.5)$ & \multirow[t]{2}{*}{0.001} \\
\hline Other & $23,031(92.8)$ & $39(0.3)$ & $13,234(99.7)$ & & $25(0.3)$ & $9,783(99.7)$ & \\
\hline \multicolumn{8}{|l|}{ Occupation } \\
\hline Laborer & $15,208(61.2)$ & $40(0.4)$ & $11,162(99.6)$ & \multirow[t]{4}{*}{0.343} & $14(0.3)$ & $3,992(99.7)$ & 0.001 \\
\hline Small/medium enterprise & $337(1.4)$ & $1(0.8)$ & $122(99.2)$ & & $7(3.3)$ & $207(96.7)$ & \\
\hline Large industry & $9,181(36.9)$ & $7(0.3)$ & $2470(99.7)$ & & $22(0.3)$ & $6,682(99.7)$ & \\
\hline Home-Maker & $138(0.6)$ & $0(0.0)$ & $0(0.0)$ & & $1(0.7)$ & $137(99.3)$ & \\
\hline
\end{tabular}

\section{Discussion}

The occupational pattern and perceptions observed in a study in China indicated employment conditions associated with HIV risk. Intervention strategies should tailor to address factors related to the occupation [12]. Migrants in our study were from the districts of Mumbai and Thane of Maharashtra, the preferred destinations for migrants from all over India. Our study findings were therefore, to a major extent, applicable to a national representation. Especially for migrants, what strategy worked and what did not work in different settings, was not evidenced. Scaling up of interventions requires careful understanding of risk profile [1]. In our study, we tried to compare the findings between two districts, Mumbai and Thane. Our study was a unique effort 
Table 2. Predictors of HIV infection among migrants in Mumbai and Thane

\begin{tabular}{|c|c|c|c|c|c|c|c|c|}
\hline \multirow[b]{2}{*}{ Factor $(n)$} & \multicolumn{4}{|c|}{ Mumbai } & \multicolumn{4}{|c|}{ Thane } \\
\hline & $\begin{array}{l}\text { HIV+, } \\
n(\%)\end{array}$ & $\begin{array}{l}\text { HIV-, } \\
n(\%)\end{array}$ & $p$ value & $\begin{array}{l}\text { A.O.R. } \\
(95 \% \mathrm{Cl})\end{array}$ & $\begin{array}{l}\text { HIV+, } \\
n(\%)\end{array}$ & $\begin{array}{l}\text { HIV-, } \\
n(\%)\end{array}$ & $p$ value & $\begin{array}{c}\text { A.O.R } \\
(95 \% \mathrm{Cl})\end{array}$ \\
\hline \multicolumn{9}{|l|}{ Gender } \\
\hline Male $(23,908)$ & $\begin{array}{c}42 \\
(0.3)\end{array}$ & $\begin{array}{c}13623 \\
(99.7)\end{array}$ & \multirow[t]{2}{*}{0.000} & $\begin{array}{c}8.652 \\
(3.217-23.268)\end{array}$ & $\begin{array}{c}33 \\
(0.3)\end{array}$ & $\begin{array}{c}10210 \\
(99.7)\end{array}$ & \multirow[t]{2}{*}{0.198} & $\begin{array}{c}1.839 \\
(0.727-4.653)\end{array}$ \\
\hline Female (956) & $\begin{array}{c}6 \\
(4.4)\end{array}$ & $\begin{array}{c}131 \\
(95.6)\end{array}$ & & & $\begin{array}{c}11 \\
(1.3)\end{array}$ & $\begin{array}{c}808 \\
(98.7)\end{array}$ & & \\
\hline
\end{tabular}

Age group

\begin{tabular}{l|c|c|c|c|c|c|c|c}
\hline Up to 18 years $(1,110)$ & $\begin{array}{c}1 \\
(1.0)\end{array}$ & $\begin{array}{c}1,030 \\
(99.9)\end{array}$ & 0.174 & $\begin{array}{c}0.131 \\
(0.007-2.460)\end{array}$ & $\begin{array}{c}0 \\
(0.0)\end{array}$ & $\begin{array}{c}79 \\
(100.0)\end{array}$ & - & - \\
\hline 19-24 years $(8,113)$ & 8 & 4,759 & 0.192 & $\begin{array}{c}0.226 \\
(0.024-2.112)\end{array}$ & $\begin{array}{c}5 \\
(0.1)\end{array}$ & $\begin{array}{c}3,341 \\
(99.9)\end{array}$ & 0.008 & $\begin{array}{c}0.112 \\
(0.022-0.558)\end{array}$ \\
\hline 25-35 years $(10,035)$ & 17 & 5,454 & 0.275 & 0.32 & 20 & 4,544 & 0.005 & 0.155 \\
& $(0.3)$ & $(99.7)$ & & $(0.041-2.478)$ & $(0.4)$ & $(99.6)$ & & $(0.042-0.567)$ \\
\hline $36-49$ years $(5,406)$ & 21 & 2,395 & 0.789 & 0.757 & 16 & 2,974 & 0.018 & 0.205 \\
& $(0.9)$ & $(99.1)$ & & $(0.099-5.777)$ & $(0.5)$ & $(999.5)$ & & $(0.055-0.760)$ \\
\hline$>49$ years $(200)$ & 1 & 116 & & & 3 & $80(96.4)$ & Ref & \\
& $(0.9)$ & $(99.1)$ & & & $(3.6)$ & & & \\
\hline
\end{tabular}

Education

\begin{tabular}{|c|c|c|c|c|c|c|c|c|}
\hline Illiterate $(3,331)$ & $\begin{array}{c}4 \\
(0.3)\end{array}$ & $\begin{array}{l}1,209 \\
(99.7)\end{array}$ & 0.933 & $\begin{array}{c}0.949 \\
(0.281-3.205)\end{array}$ & $\begin{array}{c}6 \\
(0.3)\end{array}$ & $\begin{array}{l}2,112 \\
(99.7)\end{array}$ & 0.715 & $\begin{array}{c}0.783 \\
(0.211-2.913)\end{array}$ \\
\hline Just literate $(3,637)$ & $\begin{array}{c}3 \\
(0.3)\end{array}$ & $\begin{array}{l}1,056 \\
(99.7)\end{array}$ & 0.957 & $\begin{array}{c}0.963 \\
(0.249-3.731)\end{array}$ & $\begin{array}{c}15 \\
(0.6)\end{array}$ & $\begin{array}{l}2,563 \\
(99.4)\end{array}$ & 0.270 & $\begin{array}{c}1.931 \\
(0.600-6.213)\end{array}$ \\
\hline Up to $5^{\text {th }}$ class $(6,902)$ & $\begin{array}{c}20 \\
(0.5)\end{array}$ & $\begin{array}{l}4,284 \\
(99.5)\end{array}$ & 0.428 & $\begin{array}{c}1.409 \\
(0.603-3.291)\end{array}$ & $\begin{array}{c}14 \\
(0.5)\end{array}$ & $\begin{array}{l}2,584 \\
(99.5)\end{array}$ & 0.429 & $\begin{array}{c}1.59 \\
(0.504-5.016)\end{array}$ \\
\hline Up to $9^{\text {th }}$ class $(6,369)$ & $\begin{array}{c}13 \\
(0.3)\end{array}$ & $\begin{array}{l}4,342 \\
(99.7)\end{array}$ & 0.963 & $\begin{array}{c}0.979 \\
(0.392-2.442)\end{array}$ & $\begin{array}{c}5 \\
(0.2)\end{array}$ & $\begin{array}{l}2,009 \\
(99.8)\end{array}$ & 0.908 & $\begin{array}{c}1.083 \\
(0.282-4.153)\end{array}$ \\
\hline $10^{\text {th }}$ and above $(4,625)$ & $\begin{array}{c}8 \\
(0.3)\end{array}$ & $\begin{array}{l}2,863 \\
(99.7)\end{array}$ & & & $\begin{array}{c}4 \\
(0.2)\end{array}$ & $\begin{array}{l}1,750 \\
(99.8)\end{array}$ & & \\
\hline
\end{tabular}

Marital status

\begin{tabular}{|c|c|c|c|c|c|c|c|c|}
\hline Married $(15,784)$ & $\begin{array}{c}38 \\
(0.5)\end{array}$ & $\begin{array}{l}7,620 \\
(99.5)\end{array}$ & \multirow[t]{2}{*}{0.471} & $\begin{array}{c}1.443 \\
(0.533-3.910)\end{array}$ & $\begin{array}{c}42 \\
(0.5)\end{array}$ & $\begin{array}{l}8,084 \\
(99.5)\end{array}$ & \multirow[t]{2}{*}{0.181} & $\begin{array}{c}3.061 \\
(0.595-15.747)\end{array}$ \\
\hline Never married $(9,080)$ & $\begin{array}{c}10 \\
(0.2)\end{array}$ & $\begin{array}{l}6,134 \\
(99.8)\end{array}$ & & & $\begin{array}{c}2 \\
(0.1)\end{array}$ & $\begin{array}{l}2,934 \\
(99.9)\end{array}$ & & \\
\hline
\end{tabular}

Mobility with

\begin{tabular}{l|c|c|c|c|c|c|c|c}
\hline Broker/contractor (2014) & 2 & 1,626 & 0.433 & $\begin{array}{c}1.765 \\
(0.427-7.304)\end{array}$ & $\begin{array}{c}1 \\
(0.3)\end{array}$ & $\begin{array}{c}395 \\
(99.7)\end{array}$ & 0.001 & $\begin{array}{c}0.116 \\
(0.033-0.416)\end{array}$ \\
\hline Groups (15,047) & 19 & 6,823 & 0.489 & $\begin{array}{c}0.497 \\
(99.9)\end{array}$ & $\begin{array}{c}27 \\
(0.069-3.597)\end{array}$ & $\begin{array}{c}8,178 \\
(0.3)\end{array}$ & 0.233 & $\begin{array}{c}(99.7) \\
(0.248\end{array}$ \\
& $(0.3)$ & $(99.7)$ & & 1.122 & 9 & 2,364 & 0.009 & 0.2 \\
\hline Alone (7,323) & 24 & 4,926 & 0.879 & $(0.255-4.936)$ & $(0.4)$ & $(99.6)$ & & $(0.060-0.668)$ \\
\hline Other type (512) & $(0.5)$ & $(99.5)$ & & & 7 & 81 & & \\
& 3 & 421 & & & $(8.0)$ & $(92.0)$ & & \\
\hline
\end{tabular}

Stay at destination

\begin{tabular}{l|c|c|c|c|c|c|c|c}
\hline$\leq 1$ year $(6,440)$ & $\begin{array}{c}10 \\
(0.3)\end{array}$ & $\begin{array}{c}2,877 \\
(99.7)\end{array}$ & 0.774 & $\begin{array}{c}0.855 \\
(294-2.488)\end{array}$ & $\begin{array}{c}6 \\
(0.2)\end{array}$ & $\begin{array}{c}3,547 \\
(99.8)\end{array}$ & 0.052 & $\begin{array}{c}0.313 \\
(0.097-1.008)\end{array}$ \\
\hline $1-5$ years $(15,085)$ & 32 & 9,450 & 0.567 & 1.308 & 28 & 5,575 & 0.934 & 0.965 \\
& $(0.3)$ & $(99.7)$ & & $(0.522-3.280)$ & $(0.5)$ & $(99.5)$ & & $(0.411-2.262)$ \\
\hline$>5$ years $(3,339)$ & 6 & 1,427 & & & 11 & 1,895 & & \\
& $(0.4)$ & $(99.6)$ & & & $(0.6)$ & $(99.4)$ & & \\
\hline
\end{tabular}


Table 2. Cont.

\begin{tabular}{|c|c|c|c|c|c|c|c|c|}
\hline \multirow[b]{2}{*}{ Factor $(n)$} & \multicolumn{4}{|c|}{ Mumbai } & \multicolumn{4}{|c|}{ Thane } \\
\hline & $\begin{array}{l}\text { HIV+, } \\
n(\%)\end{array}$ & $\begin{array}{l}\text { HIV-, } \\
n(\%)\end{array}$ & $p$ value & $\begin{array}{c}\text { A.O.R. } \\
(95 \% \mathrm{Cl})\end{array}$ & $\begin{array}{l}\text { HIV+, } \\
n(\%)\end{array}$ & $\begin{array}{l}\text { HIV-, } \\
n(\%)\end{array}$ & $p$ value & $\begin{array}{c}\text { A.O.R } \\
(95 \% \mathrm{Cl})\end{array}$ \\
\hline \multicolumn{9}{|l|}{ Staying with } \\
\hline Family members (1723) & $9(1.9)$ & $\begin{array}{c}460 \\
(98.1)\end{array}$ & 0.000 & $\begin{array}{c}4.944(2.139- \\
11.428)\end{array}$ & $\begin{array}{c}19 \\
(1.5)\end{array}$ & $\begin{array}{l}1,235 \\
(98.5)\end{array}$ & 0.000 & $\begin{array}{c}5.827 \\
(2.483-13.676)\end{array}$ \\
\hline Other $(23,031)$ & $\begin{array}{c}39 \\
(0.3)\end{array}$ & $\begin{array}{l}1,3234 \\
(99.7)\end{array}$ & & & $\begin{array}{l}25 \\
(0.3)\end{array}$ & $\begin{array}{l}9,783 \\
(99.7)\end{array}$ & & \\
\hline \multicolumn{9}{|l|}{ Occupation } \\
\hline Laborer $(15,208)$ & $\begin{array}{l}40 \\
(0.4)\end{array}$ & $\begin{array}{c}11,162 \\
(99.6)\end{array}$ & 0.581 & $\begin{array}{c}1.267(0.547- \\
2.934)\end{array}$ & $\begin{array}{c}14 \\
(0.3)\end{array}$ & $\begin{array}{l}3,992 \\
(99.7)\end{array}$ & 0.667 & $\begin{array}{c}0.846(0.395- \\
1.812)\end{array}$ \\
\hline $\begin{array}{l}\text { Small/medium } \\
\text { enterprise (337) }\end{array}$ & $1(0.8)$ & $\begin{array}{c}122 \\
(99.2)\end{array}$ & 0.509 & $\begin{array}{c}2.062(0.241- \\
17.605)\end{array}$ & $7(3.3)$ & $\begin{array}{c}207 \\
(96.7)\end{array}$ & 0.001 & $\begin{array}{c}7.971(2.999- \\
21.189)\end{array}$ \\
\hline Large industry $(9,181)$ & $7(0.3)$ & $\begin{array}{l}2,470 \\
(99.7)\end{array}$ & & & $\begin{array}{c}22 \\
(0.3)\end{array}$ & $\begin{array}{l}6,682 \\
(99.7)\end{array}$ & 0.431 & $\begin{array}{c}0.412(0.045- \\
3.754)\end{array}$ \\
\hline Home-maker (138) & $0(0.0)$ & $0(0.0)$ & & & $1(0.7)$ & $\begin{array}{c}137 \\
(99.3)\end{array}$ & & \\
\hline
\end{tabular}

to explore the association between different occupations and HIV infection status of migrant workers.

The overall HIV infection rate among migrants in Mumbai was $0.34 \%$ and in Thane was $0.39 \%$. In India, HIV prevalence among male migrants was estimated to be $0.99 \%$ in 2010-11, which was three times higher than the general population [4]. Among different characteristics, gender was an influential factor. Among the female migrants, HIV infection rate was $4.4 \%$ in Mumbai compared with $1.3 \%$ in Thane. Among the males, the infection rate was $0.3 \%$ in both the places (Mumbai: $p=0.001$, OR: 8.652; Thane: $p=0.198$, OR: 1.839). The gender being significant in Mumbai and not in Thane might have different connotation. We interpreted that in Mumbai, a huge number of female sex workers (flying or brothel-based) led to an opportunity for female migrants to provide sex. Female migrants often engage them in sex work $[13,14]$. Findings implied that strategies under NACP for migrants could be gender friendly. In Thane, age groups were concentrated between 19 years to 49 years (98.5\%). In Mumbai, apart from this age group (91.7\%), the concentration was more for the age group up to 18 years (7.5\%). This explained engagement of more adults and skilled population in Thane. In Mumbai, the younger population was also adequate. Younger people were 'crazy' to migrate to Mumbai, the business city in India. In Thane, among the more aged population (> 49 years), HIV prevalence was much higher (3.6\%). Mobility pattern with the other type of accompanying person (other than broker, contractor, or group) was a good predictor of HIV infection in Thane $(p=0.009$; $\mathrm{OR}=0.2 ; 0.060-0.668$ ). Adequate heterogeneity of occupation groups in Thane and comparatively poor job opportunity compared with Mumbai might have motivated migrants to move desperately with any type of accompanying person other than known groups. This led to further spread of HIV infection among them, as high as $8.0 \%$. In Thane, among workers residing for less than one year, (i.e., for a shorter duration), HIV infection rate was lower $(0.2 \%)$. When duration was higher (1-5 year or $>5$ years), infection rates also increased, respectively $0.5 \%$ and $0.6 \%$, and associations were significant ( $p=0.052$; OR: $0.313 ; 0.097-1.008)$. This was not the case for Mumbai. We interpreted that in Thane, vulnerabilities were higher, which resulted in increased infection rate when the stay was longer. The low-wage migrant labor was responsible for the externalization of HIV risk characteristics. These concepts pointed strategies to researchers and policymakers [15]. For both Mumbai and Thane, workers who were staying with their families, the infection rates were higher than those who were staying with others (Mumbai: $1.9 \%$ vs. $0.3 \%$, and Thane: $1.5 \%$ vs. $0.3 \%$ ). In a study from Thailand, factors related to visiting sex workers included marital status (more visits if not married) [16]. This could be a proxy issue related to more HIV infection. In our study, the result was different, and requires new explorative research.

For occupation, both in Mumbai and Thane, the infection rate was higher among small and medium-size industry workers (Mumbai: $0.8 \%$ and Thane: $3.3 \%$ ). For Thane, this occupation was identified as an important predictor factor $(p=0.001 ;$ OR $=7.971 ; 2.999-21.189)$. From our existing experiences under NACP, it was known that in Thane occupations were more diverse, and there were gender and power relationship in the unorganized sectors. Migrants had a heightened risk of HIV infection, which resulted from the condition and structure of the migration process, and occupation was one parameter of these conditions and structures $[7,8]$. However, why occupation in small to medium size sector was much more important, not the laborers, was our concern. Similarly, this happened to Thane and not in 
Mumbai. In a study in Mumbai, it was found that migrants employed in the textile, quarry, and construction industries had higher risks of HIV infection [17]. Our study thus puts this question to relook and assess the power and negotiation structures playing a role in Thane compared with Mumbai through an in-depth research.

Migrants moved out from their place of origin to enhance their income. Many of them were unskilled, and the type of occupation was linked to their vulnerabilities and risks of HIV infection. Type of their occupation and scope of work also influenced their mobility, sexual structure, and power relationship. In a study from 1994, the most common migrant workers were carpenters, masons, electricians, plumbers, lorry drivers, mechanics, and heavy equipment operators. These production and transport workers outnumbered the professional and technical workers [18]. NACP considered a uniform strategy for all occupation groups [1]. We assumed that migrants moved out in different occupations and engaged themselves in different occupations, which actually predicted their HIV infection rates.

Policy implication is another relevance of this article in context to designing a newer effective migrant intervention policy in India, compared to the existing policy for the migrants. Migrant workers belong to high-risk group. In the study by Yang et al., in Beijing and Nanjing, China, it was found that female migrants working in entertainment establishments or personal service (e.g., nightclubs, dancing halls, barbershops, beauty salons, massage parlors, etc.) had two times more risky sexual practices than those working in non-entertainment establishments (e.g., restaurants, stalls, domestic service, factories, etc.). Among 1,543 female migrants studied, $10 \%$ of women in the entertainment establishments had sold sex, 30\% had multiple sex partners, and $40 \%$ had sex with men who had multiple partners. The rate of consistent condom use was less than 15\% [19]. In Tanzania, women working in bars were at higher risk of HIV infection [20]. The National AIDS Control Strategy in India aimed at strengthening implementation of workplace policy, meeting the needs and vulnerabilities of migrants [21]. Migrant intervention strategies were revised so that vulnerable migrants and their family who are socially and economically marginalized. New strategies in India included the link worker scheme reaching out to high-risk women in rural areas including spouses of migrants in 208 vulnerable districts. Another two types of newer strategies considered were behavior change communication through link workers and communication campaign in high migrant source districts. The National Migrant Strategy provided services for migrant at the source, in transit, and at the destination. A revised migrant strategy was designed to cover the needs of married migrants [22]. Female migrants were also addressed, as they were more vulnerable to HIV because they were often forced into transactional sex, either through coercion or to supplement their income. This happened due to lack of knowledge, negotiation skills, and decision-making power [21]. The key issue of migration is the occupation for which people move. Strategies never addressed different types of occupation and vulnerabilities due to different occupations. In our study, we gathered evidence in Thane how different types of occupations could influence HIV infection rate. This information can be helpful for policy formulation, how specific strategies may be adopted in migrant intervention. However, the describing details of strategies to be helpful for intervention were not the scope of this study. To better inform the policy detailing the key strategies, additional research is needed that overcomes the limitation of this research.

\section{Conclusions}

Our study could identify gender and type of person residing with the migrant at the destination as important predictors of HIV infection among the migrants in Mumbai. Whereas in Thane, age group, type of person staying with the migrant at the destination, mobility pattern, and occupation in small and medium-size industries (diamond, dairy, moti and quarry work) predicted higher HIV infection rates. Findings contributed to a greater understanding of the HIV epidemic pattern among migrants in connection with a new area to emphasis that types of the occupation of the migrants was overlooked by the policy makers. The study findings, therefore, conclude that special strategies need to be developed to address the occupation-specific needs of the migrants. Occupation is the driving force of the migration and mobility. A policy without addressing that aspect perhaps cannot be very much effective. An in-depth research is recommended to better inform the policy to identify the key strategies addressing the special needs of the different types of occupations of the migrants.

\section{Acknowledgments}

The information has been collected from the project entitled 'impact through prevention, private sector and evidence-based programming (PIPPSE)', implemented by Public Health Foundation of India. We extend sincere thanks to the USAID as a partner of the project. We also thank different stakeholders of State AIDS Control Society (SACS), Maharashtra and District AIDS Project Control Unit, Thane in Maharashtra, India. We sincerely acknowledge the cooperation of the stakeholders of National AIDS Control Organization, Government of India. The study was funded by U.S. Agency for International Development (USAID).

\section{Conflict of interest}

The authors declare no potential conflicts of interest with respect to the research, authorship, and/or publication of this article.

\section{References}

1. NACO. National AIDS Control Organization. Migrant Strategy for Targeted Interventions. NACP. National AIDS Control Program Phase IV. 2012-1. pp 20-23. 
2. Census of India. http://censusindia.gov.in/Census_And_You/ migrations.aspx. (Accessed on 8th February 2017).

3. HIV Sentinel Surveillance. A technical brief 2014-15. New Delhi: NACO. National AIDS Control Organization, Ministry of Health and Family Welfare, Government of India. 2015; p 12.

4. Indian Council of Medical Research (ICMR). National AIDS Control Organization. India HIV Estimations. Technical Report 2015. pp 17-35.

5. UNAIDS. UNAIDS Report on the Global AIDS Epidemic. 2012; pp 243-55.

6. NACO (2009). National AIDS Control Organization. Targeted Interventions under NACPIII, Operational Guidelines, Vol 1, Core High Risk Groups. 2009; pp 209-223.

Abdulkader R, Goswami K, Goswami K, et al. HIV-Risk Behavior Among the Male Migrant Factory Workers in a North Indian City. Indian J Community Med 2015; 40: 108-115.

7. Saggurti N, Verma RK, Jain A, et al. HIV risk behaviors among contracted and non-contracted male migrant workers in India: Potential role of labour contractors and contractual systems in HIV prevention. AIDS 2011; 22: 127-136.

8. Nishigaya K. Female garment factory workers in Cambodia: migration, sex work and HIV/AIDS. Women Health 2002; 35: 27-42.

9. Awasthi KR, Adefemi K, Tamrakar M. HIV/AIDS: A Persistent Health Issue for Women and Children in Mid and Far Western Nepal. Kathmandu Univ Med J (KUMJ) 2015; 13: 88-93.

10. Singh DP. Migration and occupation in Mumbai: issues and implications. Tata Institute of Social Sciences. 2015; pp 3-4. demoscope. ru/weekly/knigi/tours_2005/papers/iussp2005s50938 (Accessed on $24^{\text {th }}$ February 2017).

11. Yang H, Li X, Stanton B, et al. Workplace and HIV-related sexual behaviors and perceptions among female migrant workers. AIDS Care 2005; 17: 819-833.

12. Weine S, Golobof A, Bahromov M, et al. Female migrant sex workers in Moscow: gender and power factors and HIV risk. Women Health 2013; 53: 56-73.

13. Organista KC, Organista PB, Garcia DAJ. AIDS and condom-related knowledge, beliefs, and behaviors in Mexican migrant laborers. Hisp J Behav Sci 1996; 18: 392-406.

14. Hirsch JS. Labor migration, externalities and ethics: theorizing the meso-level determinants of HIV vulnerability. Soc Sci Med 2014; 100: 38-45.

15. Rao N, Jeyaseelan L, Joy A, et al. Factors associated with high-risk behaviour among migrants in the state of Maharashtra, India. J Biosoc Sci 2013; 45: 627-641.

16. Ford K, Chamrathrithirong A. Sexual partners and condom use of migrant workers in Thailand. AIDS Behav 2007; 11: 905-914.

17. Abela MI. Labour migration from South and South-East Asia: some policy issues. Int Labour Rev 1984; 123: 491-506.

18. Mgalla Z, Pool R. Sexual relationships, condom use and risk perception among female bar workers in north-west Tanzania. AIDS Care 1997; 9: 407-416.

19. Yang H, Li X, Stanton B, et al. Workplace and HIV-related sexual behaviours and perceptions among female migrant workers. AIDS Care 2005; 17: 819-833.

20. National AIDS Control Organization (NACO). Government of India. Targeted Intervention for Migrants. Operational Guidelines 2007; 11-42.

22. Social Assessment for NACP IV. Social Assessment Report. National AIDS Control Programme NACP III. Department of AIDS Control. Ministry of Health \& Family Welfare. Government of India, 2012; $12-51$. 